Ann. Biol. anim. Bioch. Biophys., I975, 15 (2), 303-3I5.

\title{
THE USE OF PROGESTAGENS IN SHEEP BRED BY NATURAL AND ARTIFICIAL INSEMINATION
}

\author{
I. GORDON \\ Faculty of Agriculture, \\ University College Dublin, Lyons Farm, \\ Newcastle P. O., Co. Dublin (Ireland)
}

SUMMARY

Research in controlled breeding in sheep, based on the intravaginal sponge, has been actively pursued in Ireland for the past ro years. Some encouraging progress has been made in the commercial exploitation of the new breeding techniques. It is now certain that hormone applications can be extremely effective when used under certain specified treatment and management conditions. It is also probable that further research and development will permit their successful application over a wide range of sheep production systems.

\section{INTRODUCTION}

For more than 40 years, workers around the world have examined the possibility of employing hormones in the control of mating and fertility in sheep. The fact that most ewes in the agriculturally productive countries are seasonal breeders and often produce smaller lamb-crops than farmer would desire has made sheep a rather obvious target for the physiologist's attentions. Progress towards commercially acceptable hormone techniques was greatly accelerated in the I950's with the elucidation of the role of progesterone in facilitating the induction of coincident oestrus and ovulation and with the availability of the highly potent progesterone derivatives.

A major advance was the work of Robinson (I964) showing that progestagens can be administered in physiologically active doses over the required period of about two weeks by the intravaginal route. Without recourse to needless historical detail, most attempts in controlled breeding up to I 964 centred around a series of progestational injections or oral administrations with or without serum gonadotrophin (PMSG) ; quite apart from the fact that oestrous response and conception 
rate left much to be desired, the time and labour which was involved remained a major factor against their acceptance in commercial farming. Much of the work in controlled breeding in sheep in the U. K. and Ireland in the I950's and early sixties was concerned with attempts to simplify the progestagen administration procedures down to the point at which techniques might be useful to farmers (CROWLEY, I964; GoRDON, 1958, r963).

\section{UCD Sheep research programme (1964-74)}

Ten years ago, a sheep research programme was initiated in University College Dublin based on the use of the progestagen-impregnated sponge. It seemed, at that time, that the intravaginal sponge technique could be the solution to one major problem which had previously debarred farm applications. In the years since then, data have accumulated in several areas of controlled breeding (see fig. I) for about

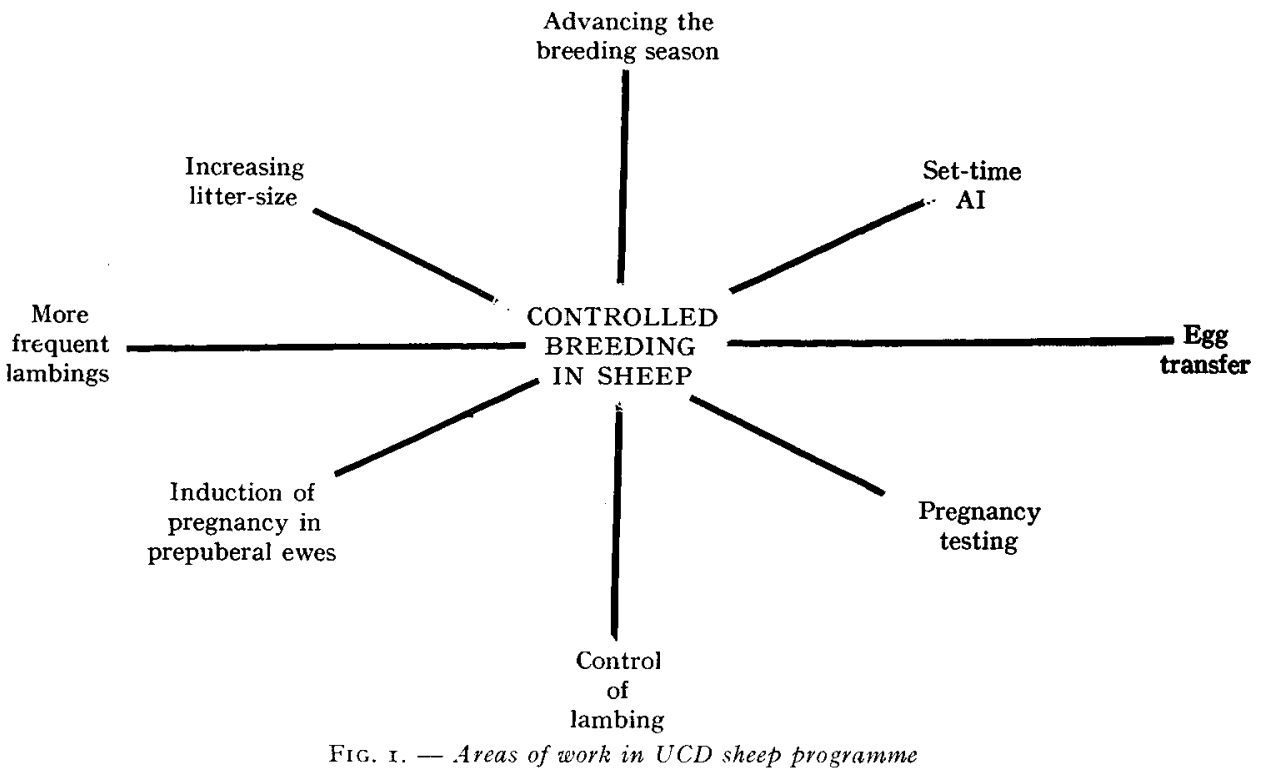

$4^{0,000}$ intravaginal treatments, most of these sheep being distributed on more than 500 farms in nearly every county of the Republic. In addition to controlled breeding applications made directly by workers from UCD, FGA-Progesterone sponges prepared in the College have been made available to researchers in several parts of the U. K.

From the work already conducted, it is certain enough that some controlled breeding measures can be put to immediate economic use by the Irish lowland sheep farmer. Indeed, in the Summer of I973, a sheep farmer in most parts of Ireland could, for the first time, get the services of his local cattle AI station in treating his sheep with intravaginal sponges and PMSG for early-lamb production. The charge of $60 \mathrm{p}$. per ewe ( $35 \mathrm{p}$. of this for the sponge and PMSG), covered two visits by a technician, the first to insert the sponge, the second, I4 days later, to remove the device 
and inject the ewe with serum gonadotrophin. On the economic front, the extra costs involved in early-lamb production worked out at about $£ 2 /$ lamb, including the cost of hormone treatment and extra feeding, whereas the increased net returns in 1974 were at least $£ 6 / \mathrm{lamb}$; this was due to the fact that prices were $47 \mathrm{p}$. $/ 1 \mathrm{~b}$. in April in contrast to $30 \mathrm{p}$. / $\mathrm{lb}$. by July.

The hormonal techniques do, however, need to be applied under appropriate animal husbandry and management conditions, by people thoroughly conversant with them. Considerable emphasis is placed on having sheep in good nutritional condition and in minimising adverse effect arising from stress in the application of treatments. For such reasons, a Controlled breeding service has been operated on an experimental basis from UCD for the past several years, much of the work being done in collaboration with Government Advisory Services and with the financial support of the country's Department of Agriculture. One of the early aspects covered was the performance of lowland Irish sheep in the normal autumn season as a guide to what might be expected with a fully effective hormonal regime (table I). These and other background data were collected on the University farms and elsewhere in the mid-I960 s.

TABIE I

Lambing outcome in 51 untreated sheep flocks bred in the autumn season

\begin{tabular}{|c|c|c|c|c|c|}
\hline & Ewes bred & Gave birth & Lambs born & $\begin{array}{l}\text { Conception } \\
\text { rate }(\%)(\mathbf{1})\end{array}$ & $\begin{array}{l}\text { Lambs per } \\
\text { conception }\end{array}$ \\
\hline First services & & 1,608 & $\geq, \geq 66$ & 80.8 & 1.41 \\
\hline First and second services & & 1,845 & 2,564 & 92.7 & 1.39 \\
\hline
\end{tabular}

(1) Ewes that gave birth as p. 100 of those bred.

\section{Field testing}

The development of techniques during the past decade has been greatly aided by the participation of sheep farmers in an extensive field testing programme. Experiments have been kept as simple and straightforward as possible, with small groups of sheep (no more than $25^{-5}$ ewes), on a relatively large number of farms, being placed on treatment; each sheep has been identified by ear-tag and a large number printed on its coat. This allows the farmer to record the progress of the sheep in detail. This field testing work, done without charge to the farmer, can be one means of providing data, generated in a short space of time from a considerable number of sheep. Some of these data are presented in the present paper, wich covers controlled breeding applications in more than 20,000 ewes. A not inconsiderable amount of testing over the years has yielded data of little interest in advancing the commercial application of controlled breeding, and this is not dealt with. The present discussion concentrates on the positive aspects of progestagen treatment in sheep and points up a few observations not previously emphasised. 


\section{I. - EVOLUTION OF PRESENT TECHNIQUES}

A great deal of the UCD work has been among "dry " ewes in late anoestrus ; it is in this category that Irish sheep farmers are most willing to participate. As part of the initial Australian work in intravaginal applications, experiments in late anoestrus with breeds of British origin suggested that treatment with Fluorogestone acetate $\left({ }^{1}\right)$ (FGA) impregnated sponges alone might be effective in advancing the breeding season of sheep by several weeks (RoBInson and SMiтH, I967). Field trials conducted by GoRDON and KEANE (r967) in the mid-r960's by UCD with FGA sponges clearly showed that PMSG (500 IU was the dose chosen) was essential in conjunction with the intravaginal treatment if an acceptable oestrous response was to be induced in the month of July (late anoestrus for sheep in Ireland). After other preliminaries, in which the antibiotic dusting of sponges became part of the routine, a standard procedure for early breeding was adopted, involving FGA intravaginal treatment for two weeks and a single dose $1 / \mathrm{m}$ of PMSG at withdrawal. Rams joined ewes ( $\mathrm{I}: \mathrm{IO}$ ) ratio at progestagen withdrawal and remained for at least three weeks to breed ewes at the first and second heat periods. General management and husbandry aspects were in accord with experiences among synchronized sheep in the I950's.

TABLE 2

Outcome of "Early-breeding " applications in 1968-71 as compared with 1965-67

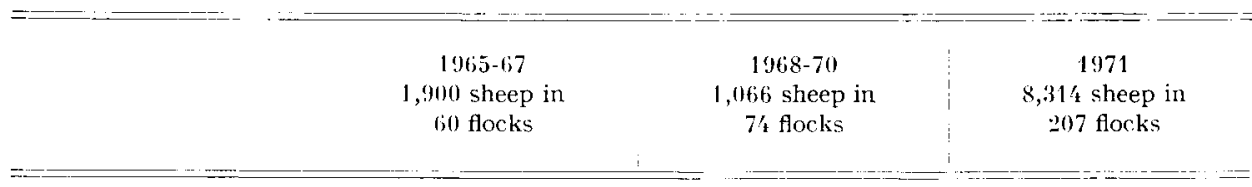

Outcome per 100 ewes exposed to rams

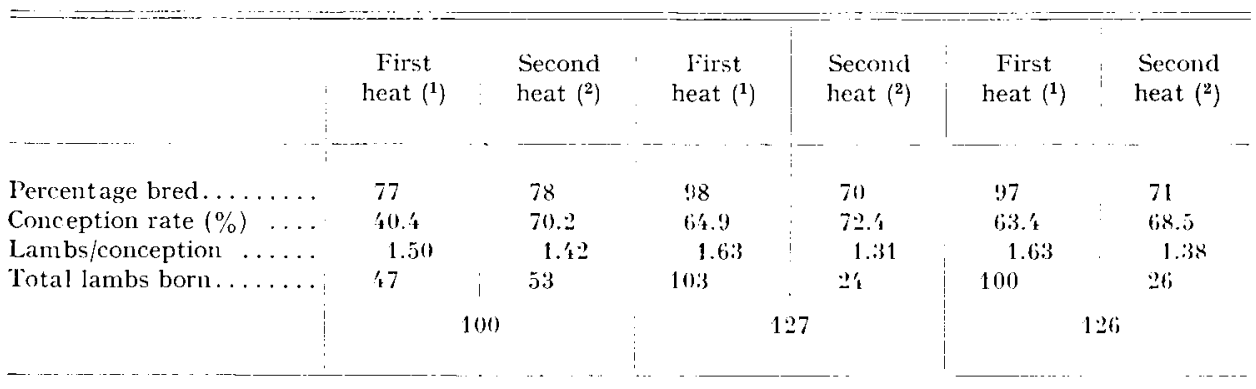

(1) Ewes-treated with FGA (30 mg) pessaries and a dose of 500 IL PMSG at progestagen withdrawal. Rams introduced at the end treatment at $10 \mathrm{p}$. 100 level and allowed to mate freely with ewes.

(2) These data relate to those ewes which did not conceive at the time of first heat.

(1) $9 \alpha$-fluoro-I I $\beta$-hydroxy-I $7 \alpha$-acetoxy-progesterone; SC-9880; ${ }^{*}$. I). Searle. 


\section{Early testing of FGA-PMSG applications}

FGA-impregnated sponges were tested in flocks over a period of three summers $(1965-67)$. Data for untreated sheep exposed to rams in these flocks at this time clearly showed the incidence of spontaneous breeding activity to be negligible (Gordon et al., I969). In summary (see table 2) somewhat less than 80 p. Ioo of the $I, 900$ ewes treated were bred in the first few days after treatment; of these, little more than $4^{\circ} \mathrm{p}$. Ioo became pregnant at the controlled oestrus. There was, however, a marked tendency for the FGA-PMSG treatment to initiate regular cyclic breeding in a high percentage of sheep, and for that reason many ewes returned spontaneously to the ram after one ovarian cycle, at which time they conceived reasonably well. About 69 p. Ioo of the total sheep treated became pregnant, either at first or second heats, and produced an average of roo lambs per roo ewes. Of these roo lambs, however, less than half were born to services at the controlled oestrus. This level of conception performance was far below that expected in this type of lowland sheep.

\section{Modifying the FGA-impregnation procedure}

In I968, a new impregnation procedure was adopted at UCD to ensure that the $30 \mathrm{mg}$ FGA dose was evenly deposited in micro-crystalline form throughout the sponge material (GoRdon, I97I $a$ ). Having tested this against the FGA-sponges used at that time, this " dispersed " sponge formed the standard intravaginal treatment employed during the next three summers (I968-I970). Other work conducted in I 968 gave evidence of a small but significantly higher conception rate and littersize in ewes that received a combination of $30 \mathrm{mg} \mathrm{FGA} / 400 \mathrm{mg}$ progesterone (GorDON, I97I $b$ ) ; this treatment was often employed subsequently when seeking optimal lambing outcomes. The oestrous response of $97-98 \mathrm{p}$. Ioo obtained in the I968-70 period under field conditions, can only be considered remarkable; conception rate at the controlled oestrus also became commercially acceptable. In the spring of $197 \mathrm{I}$, the Irish Department of Agriculture agreed to sponsor a two-year experimental " early-lamb" scheme to examine the response of sheep over a countrywide range of breed and husbandry conditions. Under this scheme, people trained at UCD dealt with rather more than I0,ooo ewes; mating and lambing results were collected for 8,314 of these (detailed in table 2 ).

\section{Ram management systems}

In using natural service as the method of breeding FGA-PMSG synchronised sheep, the standard routine involved a I : Io ram/ewe ratio and putting the males among the ewes when terminating hormonal treatment. In the summer of I970, comparisons were made between this - standard-procedure and a new alternative in which ram introduction was delayed until 48 hours after progestagen withdrawal. It was expected, on the basis of substantial data collected at UCD on the timing of heat onset and termination in FGA-PMSG treated sheep, that the majority of ewes would be some hours into oestrus by 48 hours post-withdrawal. If rams behave as PEPELKO and CLEGG (I964) and HULET (I966) report, preferring to breed ewes fresh in oestrus and recently unmated, it could be expected that the initial ejaculates 
(with the highest sperm content) would be distributed more evenly than in the standard procedure. Some preliminary field data collected in 1970-7I are summarized in table 3 from work done by GoRDON et al. (I972) ; there was a significant and useful improvement in conception rate at the controlled oestrus.

TABLE 3

IIating and lambing outcome in relation to ram management procedure (Summer, 1970)

GORDON, WHIRISKEY and JOYCE (I972)

\begin{tabular}{l}
\hline $\begin{array}{l}\text { Procedure and number } \\
\text { of farm flocks observed }\end{array}$ \\
\hline $\begin{array}{l}\text { Rams in at progestagen } \\
\text { withdrawal }(32)\end{array}$
\end{tabular}

(1) Ewes treated with FGA, F(iA/progesterone and progesterone sponges in conjunction with 250 to $700 \mathrm{IC}$ PMSG.

In the following summer, studies of mating behaviour in UCD flocks by JOYCE (I972) provided further evidence that delaying the introduction of rams until $4^{8}$ hours could significantly increase conception rate at the controlled oestrus (table 4). There was no clear evidence that " hand-service " at 48 hours led to concep-

\section{TABLE 4}

Mating and Lambing outcome in the UCD flock in relation to ram management system (JOYCE, 1972)

\begin{tabular}{|c|c|c|c|}
\hline & Sheep $\left({ }^{1}\right)$ & $\begin{array}{c}\text { Conceptions at } \\
\text { the controlled } \\
\text { oestrus }\left({ }^{2}\right)\end{array}$ & $\begin{array}{l}\text { Lambs per } \\
\text { conception }\end{array}$ \\
\hline $\begin{array}{l}\text { Ewes given a single } \\
\text { " hand-service " at } 48 \text { hrs } \\
\text { and left with rams (l) }\end{array}$ & bi & $71.7 \%$ & 1.66 \\
\hline $\begin{array}{l}\text { Ram in at progestagen } \\
\text { withdrawal (II) }\end{array}$ & 130 & $51.8 \%$ & 1.64 \\
\hline Ram in at $18 \mathrm{hrs}$ (III) & (6) & $80.7 \%$ & 1.70 \\
\hline
\end{tabular}

(1) Ewes treated with progestagen-PMSG in late anoestrus 1971.

(2) Conception rates in I and III significantly different from that in $I$. 
tion rates superior to those in normal paddock matings. The view has been expressed in Ireland that subfertility in the progestagen-treated ewe can be overcome by employing " hand-service " rather than unsupervised matings (JENNINGS and CrowLEY, I970) but present UCD evidence indicates that rams may be managed so as to distribute their ejaculates more evenly and timely by simpler means. In this, it is regarded as essential for rams to be sexually experienced; young untried males can be both inconsistent and unpredictable in their mating performance. Experience also suggests that group size should not exceed 50 ewes and 5 rams.

In the second and final year of the Department's " early-lamb " scheme the introduction of rams at 48 hours was used by UCD throughout. Data in table 5 allow a comparison between the two years. Efforts were made to recover mating

TABLE 5

Lambing outcome in large-scale farm applications in late anoestrus of $30 \mathrm{mg} F G A-500$ IU PMSG treatment

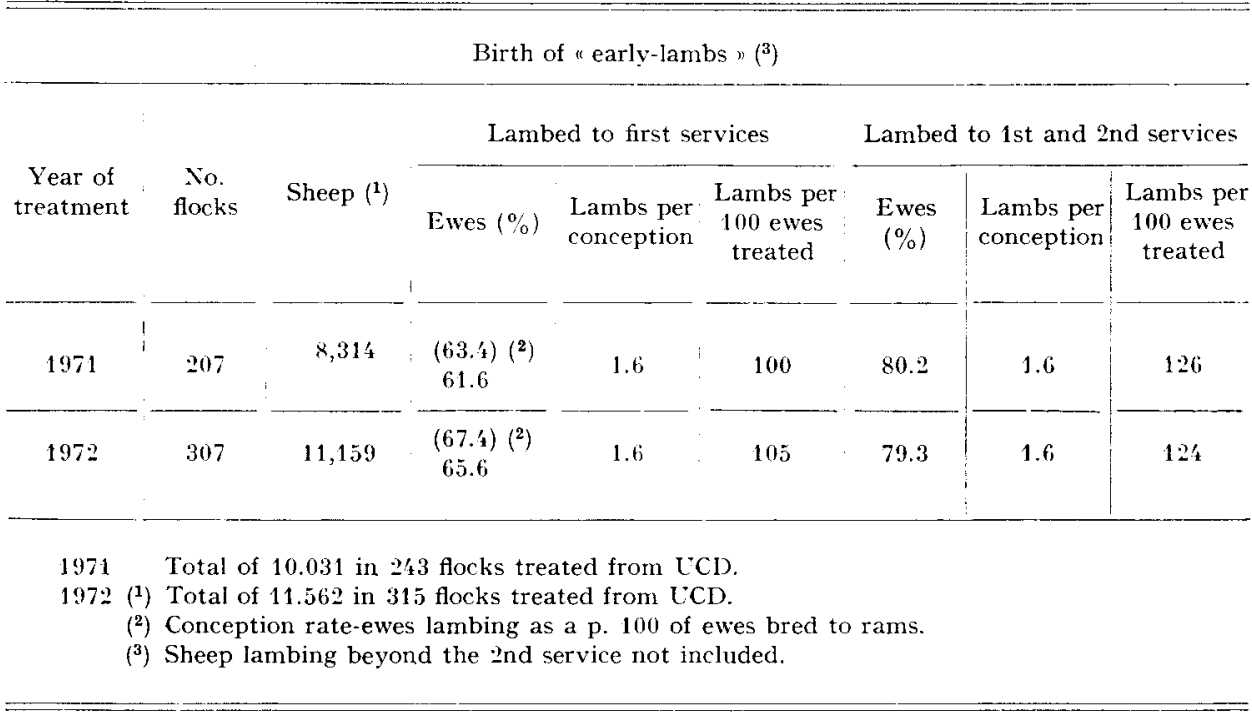

and lambing records from as many farmers as possible to avoid bias in results; in the second year, retrieval methods were sufficiently organized that results were obtained for 307 of the $3 I_{5}$ flocks $(97.5 \mathrm{p}$. IOo) treated by operators from UCD. The results for 1972 are not in conflict with the view that the higher conception rate at the controlled oestrus (67.4 p. Ioo vs. 63.4 p. Ioo) may have been related to the modification in ram mating routine.

\section{Type of progestagen employed in intravaginal applications}

Although a wide range of progestational agents are now available, few can be considered in any way suitable for controlled breeding in sheep. Australian research indicated that only compounds with characteristics almost identical to progeste- 
rone, especially in having an extremely short half-life are likely to be suitable; efforts at Sydney were largely concentrated on one such compound - FGA - shown by SHELTON (I965) to have 25 times the potency of progesterone in the inhibition of ovulation. Unlike other highly active progestagens examined, FGA did not appear to depend on retarded inactivation for its potency. The evaluation of medroxyprogesterone acetate (MAP) by the intravaginal route was undertaken by the Sydney group and appeared to be less predictable than FGA (RoBINson, r967) ; however, the fact that no comprehensive data dealing with a comparison of the two compounds were available led to some recent UCD work on this aspect.

An evaluation was made of two sponges currently prepared by commercial concerns; these are the $60 \mathrm{mg}$. MAP-impregnated Veramix (Upjohn, Crawley, U. K.) or the $30 \mathrm{mg}$ FGA-impregnated Synchromate (Searle, High Wycombe, U. K.). Included in the evaluation were three types of sponges prepared at $U C D$, the $F G A$ dispersed being the standard one employed in the earlier Department sponsored trials. Data in table 6 show that MAP at $60 \mathrm{mg}$ was as effective as $30 \mathrm{mg}$ FGA under

TABLE 6

Mating response and lambing outcome in dry anoestrus sheep in relation to progestagen content of the sponge employed

BOLAND et al. (1974)

\begin{tabular}{|c|c|c|c|c|c|c|}
\hline & \multicolumn{2}{|c|}{ Commercial } & \multicolumn{3}{|c|}{ Prepared at UCD } & \multirow[b]{2}{*}{$\begin{array}{l}\text { All treatments } \\
(80 \text { flocks) (1) }\end{array}$} \\
\hline & $\begin{array}{l}60 \mathrm{mg} \\
\mathrm{MAP}\end{array}$ & $\begin{array}{l}30 \mathrm{mg} \\
\mathrm{l} \mathrm{GA}\end{array}$ & $\begin{array}{c}30 \mathrm{mg} F G A \\
+250 \mathrm{mg} \\
\text { prog. }\end{array}$ & $\begin{array}{l}1,000 \mathrm{mg} \\
\text { prog. }\end{array}$ & $\begin{array}{l}30 \mathrm{mg} \text { FGA } \\
\text { "dispersed" }\end{array}$ & \\
\hline Sheep. . . . . . . . . . & 440 & 431 & 449 & $4 / 48$ & 440 & 2,208 \\
\hline Bred at 1 st heats $(\%)$ & 96.8 & 98.1 & 98.4 & 94.1 & 96.3 & 96.8 \\
\hline 1st heat conception $(\%)$. & 75.6 & 72.6 & 73.3 & 74.7 & $73 . .^{\prime}$ & $73.9\left({ }^{2}\right)$ \\
\hline Lambs/conception ...... & 1.62 & 1.61 & $1.6 \pm$ & 1.'1't & 1.61 & 1.58 \\
\hline Lambed-1st heats $(\%) \ldots$ & 73.0 & 70.9 & 72.0 & 66.2 & 70.3 & $70.5\left(^{3}\right)$ \\
\hline Lambs $/ 100$ ewes $\ldots \ldots \ldots$ & 118 & $11 / t$ & 116 & 95 & 113 & 111 \\
\hline $\begin{array}{l}\text { Lambed }-1 \text { st and and } \\
\text { heats }(\%) \ldots \ldots \ldots \ldots \\
\text { Lambs }(100 \text { ewes, } 1 \text { st and }\end{array}$ & 82.4 & 81.9 & 84.0 & 83.6 & 83.1 & 83.0 \\
\hline 2nd $\ldots \ldots \ldots \ldots \ldots$ & 133 & 129 & 132 & 119 & 132 & 129 \\
\hline
\end{tabular}

(1) All ewes received 500 IU PMSG (Intervet) at progestagen withdrawal and were bred by natural service.

${ }^{(2)}$ Conception rate is the p. 100 of ewes bred which lambed at that service.

(3) These figures are the p. 100 of total sheep treated which lambed.

the particular conditions of this study. Small-scale comparisons which have been recently made between FGA and MAP in which artificial insemination has been the method of breeding indicate essentially similar conception results for the two compounds. 
Data in table 6 do, however, show a significantly lower value for lambs per conception in ewes treated with progesterone sponges than in those receiving the more potent progestagens (I.44 vs. r.6I/I.62). The fact that ovulation rate and lambing outcome can be markedly affected by the type of progestagen treatment employed has been previously observed, (GoRDON, I970, I973). Such results are currently interpreted as evidence that some progestagen treatments block gonadotrophin release to a greater degree than others and that this may result in a greater surge of endogenous gonadotrophin at progestagen withdrawal. The relationship between progestagen treatment and ovulatory response is a factor to be kept in mind; in lamb production under Irish conditions, the twinning percentage is of considerable importance. Although additional ovulations can be obtained after a fashion by increasing the PMSG dose level, the principle followed at UCD is to keep the gonadotrophin at the very minimum compatible with an acceptable ovulatory response.

\section{II. - ARTIFICIAL INSEMINATION}

\section{AND INCREASED LITTER-SIZE}

An effective sheep AI technique could offer the Irish sheep farmer several clear advantages over natural service in the type of controlled breeding applications which are used in the country. Until recently, however, conception rates after AI in progestagen-treated ewes have been quite unacceptable in the general run of reports. Small-scale studies in sheep AI have been pursued at UCD during the past ten years, mainly in evaluating different approaches; it was not until I973 that the farm-scale applications were attempted seriously. The present approach is based wholly on that of Colas et al. (I968). Results in table 7, summarize the outcome

TABLE 7

Lambing outcome in 502 FGA-PMSG treated sheep in relation to method of breeding and dose level of $P M S G$

Boland et al. (1974)

\begin{tabular}{|c|c|c|c|c|c|c|c|c|}
\hline & & \multicolumn{2}{|c|}{ Sheep } & Lambed & Lambs & Pregnancy & Lambs per & $\begin{array}{l}\text { Lambs per } \\
100 \text { ewes }\end{array}$ \\
\hline \multirow{2}{*}{$\begin{array}{l}\text { Method of } \\
\text { breeding }\end{array}$} & \multirow{2}{*}{$\begin{array}{l}\text { AI } v s \text { nat. } \\
\text { service }\end{array}$} & AI & 258 & 173 & 301 & 67.1 & $1.7_{t}^{\prime}$ & 117 \\
\hline & & NS & 241 & 178 & 330 & 73.0 & 1.85 & 135 \\
\hline \multicolumn{2}{|c|}{ Totals } & - & 502 & 351 & 631 & 69.9 & 1.80 & 126 \\
\hline \multirow{2}{*}{$\begin{array}{l}\text { PMSG } \\
\text { dose }\end{array}$} & $375 \mathrm{IU}$ & 375 & 250 & 172 & 288 & 68.8 & 1.67 & 115 \\
\hline & $750 \mathrm{IU}$ & 750 & 252 & 179 & $3^{\prime} 3$ & 71.0 & 1.92 & 136 \\
\hline \multicolumn{2}{|c|}{ Totals } & - & 502 & 351 & 631 & 69.9 & 1.80 & 126 \\
\hline
\end{tabular}


of a comparison made between artificial insemination and natural service in nine flocks in the 1973 summer/autumn period. Since that time, several thousand ewes have been inseminated and the results continue to look promising.

\section{AI technique}

Pooled semen from mature Suffolk rams, stored at $\mathrm{I} 5^{\circ} \mathrm{C}$ in skim-milk ( $\mathrm{I}$,ooo million per $\mathrm{ml}$ ) is currently used in conjunction with the Cassou ministraw insemination technique. Ovulation is controlled by $30 \mathrm{mg}$ FGA-impregnated sponges and PMSG ( 375 to 750 IU). Pregnancy rate after two inseminations (200 mill. sperm in $0.2 \mathrm{ml}$ per dose) carried out at 48 and 58 hours, is shown in table 7 to be little different from that after natural service. The dose of PMSG has had little affect on the conception rate but has significantly influenced litter-size. It is evident from work so far that commercially acceptable conception rates can follow set-time artificial insemination. Litter-size can be affected as necessary to meet the farmers' requirement by choice of the PMSG dose level. This is of particular interest for many of the country's lowland sheep.

\section{Scope for increasing incidence of multiple-births}

The Galway is Ireland's major lowland breed (about 600,000 ewes) and is a large (73 kg mature bodyweight), long-wooled sheep used primarily as a fat lamb mother in matings with Suffolk rams. Although its growth potential and wool yield are acceptable, this is much less true of its lambing performance. A survey of Galway sheep production conducted by DALY (I966) on 354 farms showed a figure of no more than I.28 lambs per conception; similar statistics have been recorded elsewhere for the breed (GoRDON, I967; TrMON, I97I). A substantial amount of information has been built up over the past few years on the ovulatory response of Galway ewes in relation to various factors (season, progestagen, PMSG dose etc.). The figures in table 8 are from a study conducted in Galways at several points during the 1973-74

TABLE 8

Ovulation rate in Galway sheep in relation to $P M S G$ treatment

BOLANo et al., (1974)

\begin{tabular}{|c|c|c|c|c|}
\hline & \multicolumn{4}{|c|}{ PMSG dose level } \\
\hline & Nil & $375 \mathrm{It}$ & $750 \mathrm{IL}$ & All \\
\hline $\begin{array}{l}\text { Sheep lapped } \\
(96 \pm 2) \text { hrs }\end{array}$ & 77 & 75 & 71 & 223 \\
\hline Ovulated & 56 & 6.5 & $66 \mathrm{i}$ & 187 \\
\hline Ovulations & $69(1.23)$ & $99(1.52)$ & $138(2.09)$ & $306(1.63)$ \\
\hline
\end{tabular}


breeding season; ewes were checked for ovulatory response by laparotomy about Ioo hours after progestagen withdrawal. There was a useful and significant doseresponse relationship over the range 375 to 750 IU PMSG. The lambing outcome of Galway ewes receiving similar doses is in agreement with such data.

\section{Linking $A I$, increased litter-size and compact lambings}

A group of Texel rams has recently joined the present stud of Suffolk rams at UCD for use in set-time AI. Recent studies by An Foras Taluntais indicate a particularly promising future for the Texel in Ireland as a sire of prime lambs by virtue of its lean carcass characteristics. In linking sheep AI with progestagen-PMSG treatment, it could be possible to present Galway sheep farmers with a " package " in which an acceptable incidence of twin births is ensured in addition to compact lambing and rams of particular merit.

The AI technique as presently used is simple and can be accurately programmed. The main practical difficulty is the necessity to inseminate twice within the day. Nevertheless, the present technique is a substantial improvement on any other method of sheep AI available for farm application in Ireland to date.

\section{III. - FUTURE DEVELOPMENTS}

To be of value to the sheep-farmer, controlled breeding applications need to be simple, effective and cheap. On the first point, it may be that a simpler treatment than the progestagen-impregnated sponge will not emerge for some time. Insertion and withdrawal of sponges are operations which can be done in an instant and with the minimum of disturbance to the flock. Implants of various types have been tested at UCD, including $3 \mathrm{mg}$ SC-21009, but none has proved comparable to the regular FGA-sponge. As data on the effectiveness of treatments are presented in this paper, there is a picture of some progress in the outcome of " early breeding " and set-time AI applications. It is believed that further progress can be maintained in the years ahead, although this will probably be by way of careful attention to detail rather than any radical departure from the hormonal treatment as currently employed.

In efforts to improve sheep AI results, then the use of rams which provide the highest quality semen together with the more precise definition of the limits to be observed in dilution, storage and insemination doses are the factors to be emphasided. Among ewes destined for breeding by set-time AI, it is a question of knowing more of factors influencing the timing of ovulation (breed, nutritional status, PMSG dose, etc.). There has been no lack of reports in the literature indicating progestagens in sheep as being less than successful ; this is backed by a steadily lengthening catalogue of suspected causes of lowered fertility in progestagen-treated ewes. The UCD data on FGA-treated, sheep, however, permits the view that such ewes are indeed capable of expressing a high degree of fertility if dealt with under appropriate seasonal, nutritional and husbandry conditions. 
Finally, it must be emphasised that this paper has been confined to results dealing with dry sheep treated in the six months of the year - July to December. Nevertheless the induction of pregnancy in the post-partum ewe in the spring months of the year, especially as this is required in increasing lambing frequency has been shown to be feasible (ØRSKOv and RobINSON, I972). It is encouraging to note that sheep reproduction can now be controlled to practical advantage, given the right blend of treatment, animal and management, in a way which was not possible a few years ago.

$$
\begin{array}{r}
\text { Colloque : Control of sexual cycles in domestic animals } \\
\text { October 27-30, 1974, Nouzilly. }
\end{array}
$$

\section{ACKNOWLEDGEMENTS}

The author wishes to express thanks to G. D. SEARLE for the Company's invaluable support and encouragement in the sheep research during the period I964-74. Funcls for most of the work have been kindly provided by the Department of Agriculture and Fisheries in Dublin. Finally, a special word of thanks is due to the many farmers in Ireland who have participated in the field testing programme.

\section{RÉSUMÉ}

\section{UTILISATION DES PROGESTAGÈNES CHEZ I,A BREBIS}

\section{POUR IA REPRODUCTION PAR INSÉMINATION NATURELLE ET ARTIFICIELLE}

Les recherches sur la reproduction contrôlée chez la Brebis, basées sur l'utilisation d'éponges intravaginales, ont été poursuivies activement en Irlande durant ces ro dernières années. Des progrès encourageants ont été obtenus dans l'exploitation commerciale de nouvelles techniques de reproduction. Il est maintenant certain que les applications hormonales peuvent être extrêmement efficaces quand elles sont employées dans certaines conditions spécifiques de traitement et d'exploitation; il est aussi probable que des recherches et des progrès ultérieurs permettront leur heureuse application à un large éventail de systèmes de production ovine.

\section{REFERENCES}

Colas G., Davzier L., Courot M,, Ortavant R., Signoret J. P., I968. Resultats obtenus au cours de l'étude de quelques facteurs importants de l'insemination artificielle ovine. Ann. Zootech., 17, 47-57.

Crowler J.-P., 1964. The extension of the breeding season in sheep. Proc. 5 th int. Congr. Reprod. A. I. (Trento) 2, 378-380.

Daly P. J., 1966. Sheep husbandry survey in Kilmaine, Co. Mayo. An Foras Taluntais Publ. Dublin. Gordon I., I958. The use of progesterone and serum gonadotrophin (PMS) in the control of fertility in sheep. J. agric. Sci., 50, I23-I97.

Gordon I., 1963. The induction of pregnancy in the anoestrous ewe by hormonal therapy. J.agric. Sci., 60, $77-85$.

GoRDon I., I967. Aspects of reproduction and neonatal mortality in ewe-lambs and adult sheep. Ir. Dept. Agric. J., 64, 76-127.

Gordon I,, I970. Controlled breeding in sheep its potential application under Irish farming conditions. Ir. vet. $I ., 24,227-24 I$. 
Gordon I., I97I a. Induction of early breeding in sheep by standard and modified progestagen-PMS treatments J. agric. Sci., 76, 337-34I.

Gordon I., r97 $b$. Intravaginal oestradiol-progestagen treatments in the induction of early breeding in sheep. J. agric., Sci., 76, 355-360.

Gordon I., I973. Recent progress in controlled breeding in sheep. IVld. Rev. Anim. Prod., 9, 19-33.

Gordon I., KeANe G. M., r967. Hormonal induction of early breeding in sheep. Ir, vet. J., 21, I 22 - I 35 .

Gordon I., CafrRey W., Morrin P., I969. Induction of early breeding in sheep following treatment with progestagen impregnated pessaries and PMSG. Ir. Dept. Agric. J., 64, 3-22.

Gordon I., Whiriskey J. C., Joyce M., I972. Ram mating procedures in controlled breeding : field observations. Univ. Coll. Dublin Fac. Agric. Res. Rpt., 49-5o.

Hulet C. V., I966. Behavioural, Social and Psychological factors affecting mating time and breeding efficiency in sheep. J. Anim. Sci., 25, suppl., 5-16.

Jennings J. J., Crowley J. P., I97o. The mating of hormone treated sheep. Proc. Brit. Soc. Anim. Prod, 51st Mt., 12, 357 (Abs).

Joyce M. J. B., 1972. A comparison of three mating systems-in ewes treated with intravaginal progestagen and PMS. Proc. 7th int. Congr. Reprod. A. I. (Munich), 2, 935-938.

Orskov E. R., Robinson J. J., I972. Recent advances in ewe and lamb nutrition. Rep. Rouett Inst., 28, I I 6-I 29 .

PePElko W. E., CLEGG M. T., I964. Factors affecting recovery of sex drive in the sexually exhausted male sheep, Ovis aries. Fed. Proc., 23, 362-365.

Roninson T. J., 1964. Synchronization of oestrus in sheep by intra-vaginal and subcutaneous application of progestin impregnated sponges. Proc. Aust. Soc. Anim. Prod., 8, 47-49.

Robinson T. J., I967. Control of the ovarian cycle in the sheep. Reproduction in the Female Mammal (eds. LAming and Amoroso). Butterworth.

Robinson T. J., Smith J. F., I967. The evaluation of SC-9880-impregnated intravaginal sponges used with or without PMS for the advancement of the breeding season of British breed ewes. In : Control of the Ovarian Cycle in the sheep (ed. T. J. RoBinson) Sydney Univ. Press.

Shelton J. N., I965. Control of oestrus in sheep. Aust. vet. J., 41, I12-1x5.

TImox V. M., I97I. Improved breeding and production methods for the intensification of Irish sheep. Lamb Production, U. S. Feed Grains Counc. Publ., 69-78. 